\title{
The impact of linear investments on the spatial structure of agricultural regions
}

\author{
Edward Preweda, ${ }^{1, *}$ \\ ${ }^{1}$ AGH University of Science and Technology, Poland
}

\begin{abstract}
Linear investments cause irreversible changes in the existing shape and way of using the land located alongside it. In the case of the construction of the highway, these lands are mostly located in rural areas and prior to construction, they were used mostly in agriculture. Losses resulting from such investments affect the natural environment and landscape. Along the impact zone wind conditions change, also exhaust emissions and noise increase. Investors try to avoid the design of wide protection zones of greenery, due to the cost of buying a larger area of land and they usually use it only when it is necessary. Severe ecological losses result from land degradation, disturbances in the drainage system and changes in water relations. Such investments also have a negative impact on the profitability of agricultural holdings, in particular organic farms. The market value of land adjacent to the motorway is also decreasing. Often, on both sides of the motorway there remain land with a small area, access to the ground is difficult or even impossible. In order to reduce the negative impact of linear investments on the spatial structure of agricultural areas, infrastructure integration is carried out. The implementation of consolidations related to the construction of motorways in Poland is not a common and frequent phenomenon, which lacks concrete plans and schemes of actions. The paper presents the objectives of consolidation in the area of the village of Szczepanow in the Lesser Poland Voivodeship.
\end{abstract}

\section{Introduction}

Economic development forces the construction of highways as the most effective road connections. Currently, large linear investments are being made in Poland, above all the mentioned highways, which Poland still has a shortage of. The course of the motorway through the countryside is a source of many problems for the areas used for agriculture. The defective spatial structure of agricultural land in Malopolska [9, 10, 11], disrupted by the construction of the motorway is even more disorganized (Fig. 1)

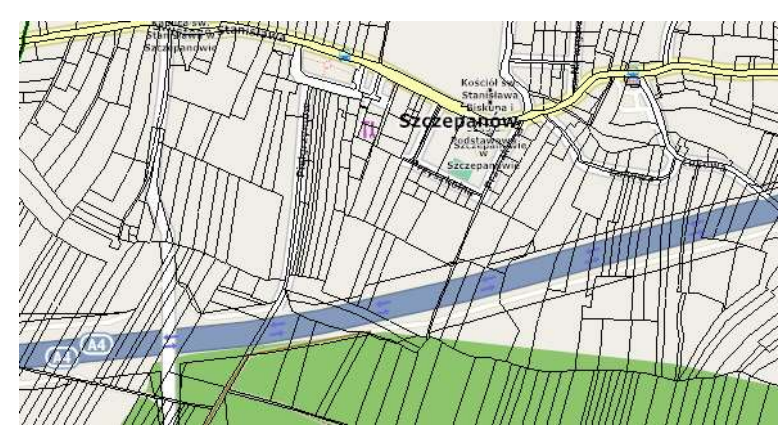

Fig. 1. Negative impact of the motorway construction "leftovers" and disruption of road infrastructure.

Source: http://brzesko.geoportal2.pl

\footnotetext{
* Corresponding author: preweda@agh.edu.pl
}

The General Directorate for National Roads and Motorways should minimize the negative effects resulting from the location of such a large investment. The construction of motorways, apart from unquestionable benefits, also sets new challenges, including the development and arrangement of the space of the land whose order has been violated. These challenges can be met through equipment and agricultural work. The main type of this type of operation is infrastructure integration $[14,15]$. The legislator provided in the Act on Merging and Exchange of Lands provisions that say that due to the deterioration of runners (this means the distribution of farm land in relation to built-up land) due to the course of existing or built public roads or railways may be initiated from merging office. Merging brings with it improvement and shaping of agricultural space as well as comprehensive modernization of the land registry.

\section{Correction of the layout of plots through merge}

The main operation causing minimizing the negative effects and repairing the disorganization of the plots layout due to the motorway in agricultural areas is the integration of infrastructure. The merger proceedings are one of the most complicated and difficult administrative matters. They are characterized by solutions having a technical character, taking into account the provisions of 
the Act on land consolidation and exchange as well as the Code of Administrative Procedure. The consolidation works make it possible to improve the spatial layout and the course of the boundaries of individual plots, by combining or dividing them, with boundaries adapted to the system of water facilities, roads and land relief [16]. These activities require mutual cooperation between land owners and state and local administration authorities. Depending on the distribution of rural space in relation to a linear investment, the infrastructure integration can be implemented in one or more consolidation proceedings.

This division and location of plots is sought, so that the new layout will be adapted both to the course of investment and the landowners' land [12]. As part of the merger, a new road system is also being designed, as well as regulating the legal status of roads that are often neglected and too narrow to meet the communication needs of landowners with regard to commuting to individual fields (each plot after consolidation gains access to a public road). It is also possible to improve water relations disturbed by the construction of the motorway. Another advantage that can be obtained is the concentration of plots of the commune, the Treasury or the Agricultural Property Agency, which gives the area for greater public investments.

The cadastral data is subject to updating, the legal status of the real estate is also highly regulated (updated in the Land and Mortgage Registers), the parcels are given a new number.

As part of the consolidation works, the boundaries of field invariants, that is, registration plots, whose layout and location remain unchanged (in accordance with the wishes of the consolidation participants) are also established [4]. It is important from the point of view of rational land use to change the spatial layout so as to improve the layout of farmsteads, parts of which are located on opposite sides of the motorway, so that access to them would be significantly longer.

Merging also allows to solve other geodetic and legal aspects, including solve old border disputes [5]. Thanks to integration, the easement may be abolished, as well as, for example, co-ownership of the land. Participants of the merger can also change the area of the farm, eg through appropriate exchanges and subsidies between farmers who want to develop agricultural activity and those who liquidate farms and end their activity in agriculture. Therefore, it is possible to exchange land for owners, as well as receiving an equivalent equivalent. These and other unmentioned advantages fully justify the need for infrastructure consolidation.

\subsection{Examining the scope and needs of consolidation}

Land consolidation related to the construction of linear investments. As a big financial challenge and a long and complicated procedure, he needs careful planning and preparation. When carrying out such an investment, it is necessary to carry out thorough analyzes of the current state in a given area. The merger proceedings require the selection of appropriate assumptions and strategies by carrying out initial preparatory works, and then precisely defining the areas on which the merger control proceedings will be conducted by the competent authority [13]. They should include areas where the negative impact of investments was found. The best would be a compromise between the sufficient implementation of the reconstruction of the spatial layout of the land, and the costs, dependent primarily on the surface of the study. The method of determining the boundaries of such an area is the subject of research, due to the lack of experience related to this type of processes in Poland. The difficulty here is the lack of clarification of the concept of "a significant deterioration in the functioning of farms in connection with the planned investment" appearing in the Act. This may cause discrepancies in the planning of the area to be integrated, which in turn may contribute to the extension of this process. Therefore, it seems advisable to bring about changes in legal provisions that would allow the integration of entire villages, and not only fragments thereof, especially when the area affected by the negative impact of the motorway covers the majority of the area [6]. The continuous development of computer software allows for the processing of geodetic and cartographic data in a digital form in such a way as to accurately determine individual solutions that can be implemented. Interesting considerations are contained in the works [7, $8,13]$.

The data and information used should be as up-to-date as possible. It is necessary to analyze the area of study in terms of soil conditions and land use, the study of ownership, the study of conditions and directions of spatial management of the commune, infrastructure (existing and planned roads, plots without access) and planning intentions. When analyzing an existing state, one should base, inter alia, on:

- Register of Lands and Buildings,

- soil and agricultural maps,

- spatial development plan of the commune,

- study of conditions and directions of spatial development of the commune,

- organization and agricultural programs,

- results of the field inventory,

- social consultations, during which the needs of the local community will be identified,

- consultations with industry institutions,

- Land and Mortgage Registers,

- Numeric Terrain Model.

It is important to outline the goals achieved by merging and determining the type and scope of plant and agricultural operations and the approximate costs of their implementation. Detailed knowledge of the conditions prevailing before the merger allows you to accurately assess the effects of consolidation in a given area, and also allows to determine the order of works carried out. Subsequent activities depend on the construction dates of the motorway. The most important, however, is the willingness to cooperate with local residents, landowners, and future participants of the merger, because merging works interfere in the right of ownership of individual legal and natural persons. On the basis of the collected materials provided to the proper district head, he decides 
to issue a decision on the commencement of consolidation proceedings or on a refusal.

\subsection{Legal basics of merging}

The main legal act regulating mergers is the Act [1]. To the extent not regulated by the aforementioned Act, the provisions of the Act [2] apply. According to the Act on Merging and Exchange of Lands (art. 3) administratively, merger and post-merger management are carried out and executed by the staroste as a task in the field of government administration. The General Directorate of National Roads and Motorways as an investor requests the starosta to initiate consolidation proceedings. A higher authority within the meaning of the Code of Administrative Procedure in relation to the county governor in matters of this scope is the voivode.

The merger is financed by the General Directorate of National Roads and Motorways, hence from the State Treasury. In the case of linear investments of a supraregional nature, the above-mentioned act in Article 4 para. 2 obliges the General Directorate for National Roads and Motorways as an investor to cover the costs of carrying out the consolidation and exchange of land and their postinstallation development, in the case of land consolidation in connection with the construction of the motorway.

\subsection{The procedure and stages of the consolidation process}

The consolidation procedure conducted in connection with the construction of the motorway can be divided into stages justified by the relevant provisions of the Act on land consolidation and exchange:

\subsubsection{Initiation of proceedings}

The decision on initiating the consolidation proceedings is issued by the staroste. Infrastructure proceedings are instituted ex officio at the request of GDDKiA. The consolidation procedure covers plots located in one or several villages or their parts. The initiation of the proceedings includes:

- Preparation of the starost's decision to initiate proceedings.

In accordance with Article 7 paragraph 1.2, it should in particular contain:

- definition of the boundaries and areas of the land consolidation or exchange area;

- list of participants of land consolidation or exchange;

- expected date of completion of consolidation or interchangeable works.

- Notification of participants about the initiation of proceedings

- According to art. 7 paragraph 3 the order to commence consolidation proceedings is read at the meeting of merge participants convened by district head, in addition, it is posted for 14 days at the offices of municipalities, where the land covered by the merger is located and on the notice boards in the villages where the land forms merge area. Based on
Article. 31 on the dates of meetings of the participants of the merger, the staroste informs the participants of the proceedings by means of a public announcement or another manner customarily adopted in a given locality.

- The deadline to lodge a complaint against the order. As soon as the 14-day deadline expires, the decision on commencing the consolidation proceedings is deemed to have been served (art.7, paragraph 4), and the order to initiate the consolidation proceedings is subject to complaint (Article 7, paragraph 6).

- A note about the consolidation proceedings in the Land and Mortgage Registers

The court competent to keep land and mortgage registers, at the district head's request, will make a record in the land and mortgage register initiating merger or exchange proceedings, and if the real property does not have a land register, the application consists of an existing set of documents (Article 21).

- Stopping the licensing of felling trees.

Pursuant to art. 15, upon the commencement of consolidation or interchangeable proceedings, including forests and forest land, the granting of permits for felling trees until the end of the proceedings is suspended, and unrealized permits are forfeited. The recipe does not apply to sanitary cuts.

- Presentation of documentation regarding the consolidation procedure.

The contractor preparing patterns of documents used during the work, documentation presenting the activity of the participants of the merger.

- Gathering the merge participants to select the councils of merge participants

According to art. 9, 1.2, the district head shall set up a council of consolidation participants, on which the selection of councils of merge participants is to be made. If the selection of the board of merge participants is not chosen within the period specified by the district head, the function of this council shall be exercised by the team appointed by the decision of that body. Its composition (in the case when a consolidation process covered one village) includes the appropriate council, a district head and a representative of the Agency being a merger participant and a representative of the socio-professional farmers' organizations. At this stage, it is important to stress the need for active participation of participants in the proceedings. Good contact with parties to proceedings at future stages is important.

\subsubsection{Estimating the value of land}

The value of the land of a given real estate before and after the merger or exchange should be the same. The same value of real estate is understood as the same value of land in terms of their production efficiency, and the same, if possible, composition of these uses, i.e. that as a result of the consolidation, such alternative lands are separated, whose agricultural production will be similar in type, quality and size to land used before consolidation. It is a relative value, i.e. the value of the land expressed in arbitrary estimation units, allowing to determine the 
appropriate replacement ratio between any land located on the merging area. For Art.8 [1], the participant may receive an equivalent in the form of land or subsidies in exchange for land previously owned, in the case when the separation of land with an equal estimated value is technically impossible or economically unjustified. An equal estimate is also a value with a difference not exceeding $3 \%$. When estimating, the provisions of the Local Development Plan should be taken into account, and if there is no study of the conditions and directions of the spatial development of the commune. In addition, the soil classification of soils should be taken into account and the classes separated should be estimated. Often, for this purpose, land classification control is needed. When determining the value in units of estimated classes, not only physicochemical properties of soils and efficiency of use should be taken into account, but also other features that increase or decrease the exchange value of a particular contour, eg land position, land reclamation, etc. Participants in the proceedings may determine by majority of the rules a comparative estimate or deem the land equivalent if the merging authority considers that this estimate is not contrary to the interests of all ownership entities. When establishing the scale of the estimated units, such numbers are used, at which the appropriate replacement ratio would be maintained not only between the classes of one use, but also between the uses. When determining the classes of land, the results of the soil classification should be used, it is possible to combine individual contours of the classification into one outline estimate as well as to divide the contours of the soil classification classification.

Procedures related to the estimation of land value:

- Authorizing the land surveyor's surveyor to carry out the land estimate and elaborate a merger project with the establishment of an advisory commission.

According to art. 10 sections 1, 2, 3 of the land covered by the merger are estimated and prepared by the merger project authorized by the starost of the surveyor-merger designer, with the participation of the advisory commission appointed by this body. The committee consists of:

1) all participants of the merger, and if the number of participants is greater than 10 persons - the board of merge participants;

2) a representative of socio-professional farmers' organizations;

3) a representative of the Agency being a merger participant;

4) representative of district head, whose area of operation are located lands covered by the merger;

5) a representative of the agricultural chamber, on whose territory the land covered by the merger is located.

The Commission shall elect a chairman from among its members. District head, at the request of the commission, may appoint appraisers to its composition.

- Mode I determine the principles of land estimation Based on Article. 11 para 1 and art. 13, 2, 3 participants of the consolidation, by way of a resolution, determine the principles of land estimate. Resolutions are passed by a three-fourths majority in the presence of at least half of the merge participants. Each participant of the consolidation proceedings is entitled to one vote. In the event of failure to adopt a resolution at the meeting convened in the first term, a resolution adopted by a majority of three-fourths of the merge participants present at the meeting convened on the second date shall be deemed valid.

- Mode II to determine the principles of land estimation According to art. 11 (1), (2) if the estimate is not determined by the merge participants, the land estimate is made on the basis of prices applicable to the sale of state agricultural real estate, including the location of the land on the integration area and their agricultural usefulness and land function resulting from the local spatial development plan. The above provision shall also apply if the staroste, by way of a decision, considers that the estimate specified in the first mode would be contrary to the legitimate interest of the participant

- Announcement of the results of the estimation of land, forests, gardens, hop gardens and other special crops.

Arranging for public inspection of the prepared map of land estimate and register of comparative land estimate. According to art. 12 (1) results of the estimation of land, forests, orchards, gardens, hop gardens and other special crops are announced at the meeting of consolidation participants convened by the staroste and then made available to public inspection for a period of 7 days in the villages included in the merger.

- Making reservations on the results of the estimation. Based on Article. 12 paragraph 2, at the meeting referred to in para. 1, and during the period of publishing the results of the land assessment for public inspection, the participants of the consolidation may raise objections to the made estimate.

- Examination of objections to the land estimate by the commission

According to art. 12 (3), the commission established under art. 10 paragraph 1 of the Act.

- To acquaint participants with the results of the commission's findings.

Based on Article. 12 (3) The Commission with the results of its findings acquaints participants of the merger at a meeting convened by district head. In the event of objections to the estimate of the land, the participants of the merger can create an additional team at this meeting, consisting of uninterested persons who will present their opinion.

- $\quad$ Mode and acceptance of the estimate of land, forests and orchards, gardens, hop gardens and other special crops.

Consent to the estimated estimate of land, forests and orchards, gardens, hop gardens and other special crops (Article $13(1,2)$ ), participants of the consolidation express in the form of a resolution that is taken at the meeting convened by the staroste. The meeting is chaired by a representative of this body. Resolutions are passed by a three-fourths majority in the presence of at least half of the merge participants. In the event of failure to adopt a resolution at the meeting convened at the first date, a resolution adopted by a majority of three-fourths of the 
merge participants present at the meeting convened in the second term shall be deemed valid.

- Mode II acceptance of estimated land, forests and orchards, gardens, hop gardens and other special crops.

According to art. 13 (4) in the event of failure to adopt the resolution referred to in para. 1, the district head, after considering the objections raised, seeking the opinion of experts and introducing possible changes, accepts the estimate of land, forests, orchards, gardens, hoppers and other special crops by means of an order subject to complaint. The consolidation participants are convened to announce the district head's decision about the results of the estimate.

- Providing the results of the estimation.

The results of the estimation of land, forests, orchards, gardens, hop gardens and other special crops are announced at the meeting of consolidation participants convened by the staroste and then made available to public inspection for a period of 7 days in the villages included in the merger (Article 12 paragraph 1).

\subsubsection{A merge project}

The implementation of the consolidation project aims to improve the structure of the land through the reconstruction of the spatial and area structure, which improves the management conditions. At the same time, environmental and landscape solutions are being implemented. Pursuant to Article 5, on the basis of the landowners' request, and in the case of land owned by the State Treasury's Agricultural Property Reserve - with the consent of the Agency, mutual exchange of land (including buildings) may take place in one or more communes. The amount of subsidies is determined according to the prices adopted when estimating the land covered by the merger or exchange. Article 14 specifies: While maintaining the value of the land from the merge, without the consent of the merge participant, the difference in land area allocated to him in relation to the land covered by the consolidation may not exceed $20 \%$ of the land covered by the merger and $10 \%$ of the previously owned land of particularly high agricultural or land suitability intended in the local spatial development plan for non-agricultural purposes.

According to art. 8 and art. 17, land necessary for the purposes of local public utility, for streets and public roads, and for the construction and maintenance or provision of basic water drainage facilities for such implementation and maintenance, is separated from the land by the State Agricultural Property of the State Treasury or commune. If in the area covered by the merger there is no land owned by the Agricultural Property Resource of the State Treasury and land of the commune, land for access roads to agricultural land or forest land is separated from the land of consolidation participants, and each of them decreases the land area to which the estimated value corresponds the ratio of the estimated value of the land earmarked for the said purpose to the value of all the land being merged. These participants are entitled to additional payments, paid by the municipality, which becomes the owner of the abovementioned land. The amount of subsidies is determined according to the prices adopted when estimating the land covered by the merger or exchange. Surcharges also apply to the separation of land with a different estimated value (difference exceeding 3\%) at the joint request of the participants of the merger, whereby:

- poviat funds are paid once, within two months after the merger is completed;

- participants pay them within two months after completing the merger into the poviat account;

- between participants are regulated directly between them;

- at the request of the participants of the consolidation process, the land owned by the State Treasury Agricultural Property Reserve subject to the proceedings may, with the consent of the Agency, be wholly or partly allocated for subsidies to the participants of the proceedings.

- Development of a land consolidation project

The project of land consolidation or exchange should take into account the arrangements of the local spatial development plan. When preparing a land consolidation project, members of the commission participate in an advisory capacity. The land consolidation or exchange project specifies the proposed boundaries of the separated land and the rules for taking possession of the land. These rules are specified in the Act.

- Designation of the project on the ground and presentation to the participants of the merger

The merger or exchange project is determined on the ground and shows participants the merge or exchange. The participants of the merger, within 14 days from the day of presenting the land consolidation project, may submit district head reservations on this project in writing. Objections to the land consolidation project are considered by the district head after consulting the commission.

- Notifying interested participants about the date and place of the committee meeting and making the inspection.

- Divisions of land communities - if applications for this type of work have been received

According to art. 25, if necessary, the commission or members authorized by it shall make an inspection. The date and place of the meeting of the committee and the inspection shall be notified to the participants of the consolidation in writing or otherwise accepted in the given place at least 3 days before the set date. The absence of interested participants of the merger at the committee meeting or during its inspection does not affect the course of its activities if the interested participants were properly notified and called to participate in these activities.

- Reviewing the reservations to the draft merge by the commission

Issuing opinions on the land consolidation project by the commission referred to in art. 10 para. 1, takes place in the presence of interested participants of the merger and at least half of the members of the commission. 
- Designation on the ground of relevant changes resulting from consideration of reservations and presenting them to participants

In accordance with art.26, each change, introduced into the merger project after its designation on the ground and presentation to the participants of the consolidation, requires re-marking on the ground and presenting to interested participants.

- District head's decision to approve the project

Under Article 27, a land consolidation project may be approved if, after being presented, the majority of merge participants did not raise any objections to it. The project of consolidation or exchange of land is approved by a staroste, by way of a decision. The decision on the approval of the project, apart from the requirements specified in kpa, should specify:

- $\quad$ area of land integration or exchange;

- dates and principles of taking possession of lands separated as a result of merge or exchange and settlement methods referred to in art. 2 para. 3 , art. 8 , art. 14 para. 1 and in art. $23 \mathrm{sec} .1$;

- the course of property boundaries in the cases referred to in the Act - Geodetic and cartographic law.

- Presentation of decisions to the merge participants. According to art. 28 paragraph 1, the decision on approval of the land consolidation project is announced by reading it at the meeting of merge participants, and also by displaying it for a period of 14 days at the offices of communes where the land is located, and on notice boards in the villages falling into the merging area. As soon as the 14-day deadline expires, the decision on the approval of the land consolidation project is considered to have been delivered to all participants.

- Disclosure of a new legal status in land and mortgage registers

The decision to approve a land consolidation or exchange project is the title to reveal a new legal status in the land and mortgage registers and the basis for introducing the participants of the consolidation into the possession of land allocated to them (Article 29). This decision does not infringe the rights of third parties to land separated in exchange for land held before merge or exchange. Loads entered in the land and mortgage registers are transferred from land subject to consolidation or exchange into land separated as a result of consolidation or exchange.

- Introducing participants to merge into the possession of land allocated to them.

Introducing the participants of the consolidation into the possession of the separated land takes place at the participants' meeting, convened by the staroste (art. 30). The date of collection is considered to be the date when the participants of the merger take possession of the newly separated land; this term is also effective in relation to participants of the merger not participating in the meeting.

\section{Land development after consolidation}

The concept of postcalcation of land was regulated by the Act of On July 29, 2011, the Act on Merging and Exchange of Lands was amended. Segment management is carried out by the staroste. These are actions thanks to which the lands are prepared for the function they are supposed to fulfill after they are merged. Generally, these are works whose task is to enable participants to take possession of their plots. These activities are financed from public funds. Specifically, they include, among others:

- building from scratch, reconstructing or reconstructing access roads to agricultural and forest land and commuting to buildings, as well as related bridges, culverts and other necessary road infrastructure buildings;

- correcting or reconstructing the course of water melioration devices, as well as improving their technical parameters (restoration, widening, appropriate reinforcement, bottoms desolation);

- adapting the land to a new development method by, for example, removing unnecessary mires and roads, reclamation (ground leveling, de-shrub removal, removal of stones, debris, roots).

The post-assembly management on the example of the drainage ditch is presented below (Fig. 2 i 3).

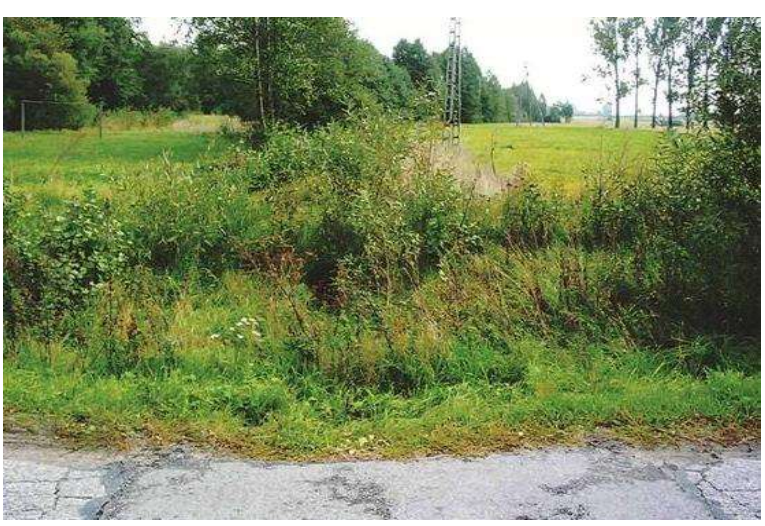

Fig. 2. Drainage before consolidation Source: http://www.kbgitr.com.pl

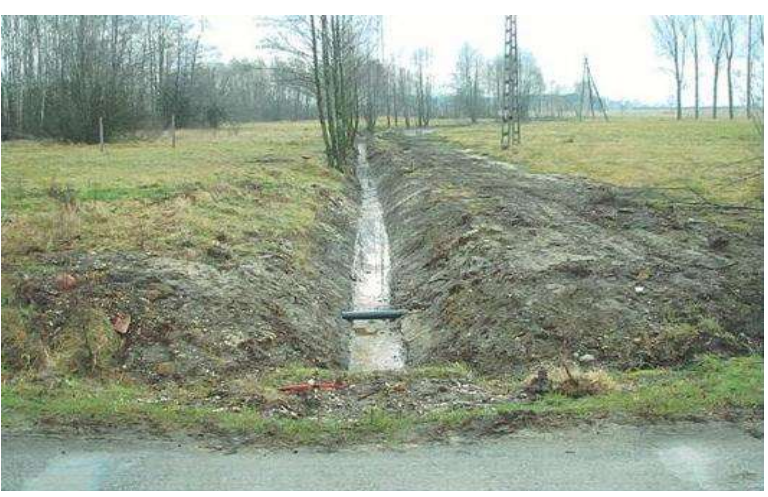

Fig. 3. Drainage after consolidation

Source: http://www.kbgitr.com.pl

\section{Merging associated with the course of the motorway A-4}

In connection with the course of a large linear investment - the A-4 motorway, the first Polish infrastructural depots started. In Małopolska, these proceedings are carried out 
by geodesy units subordinated to the self-government of the Małopolska province (mainly the Krakow Office of Geodesy and Agricultural Areas in Krakow, and to a lesser extent Małopolskie Office of Geodesy and Agricultural Areas in Tarnów) to the border with the Podkarpackie Voivodeship, where the proceedings are conducted by the Podkarpackie Office of Geodesy and Agricultural Areas in Rzeszów. The intention to include consolidation proceedings over 10 thousand. ha is a challenge and a chance for territorial units through which the motorway runs. The vast majority of farms covered by the consolidation are dispersed, small-scale farms, whose area does not exceed 10 ha.

\subsection{Mergers in the poviat Brzesko}

One of the districts through which the motorway runs is the Brzesko poviat. It is located in the north-eastern part of the Małopolska province. It covers an area of 59 thousand ha, a total of 1063 ha was covered by the consolidation process. The largest area of the Brest poviat is arable land. They constitute $47.93 \%$ of the total poviat area. A large share also belongs to forest land, constituting $20.97 \%$ of the total poviat area. The majority of land, $76.05 \%$, belongs to natural persons. Holdings not exceeding the area of 1 ha account for almost $42 \%$ of all farms. In addition, lands usually have a faulty distribution and the so-called "land chessboard" is characteristic [8, $16]$.

Table 1. Areas subject to consolidation proceedings.

\begin{tabular}{|l|c|c|}
\hline \multicolumn{1}{|c|}{ City } & Area of consolidation [ha] & $\begin{array}{c}\text { Number } \\
\text { of parcels }\end{array}$ \\
\hline Wokowice & 259 & 813 \\
\hline Sterkowiec & 167 & 785 \\
\hline Szczepanów & 323 & 1309 \\
\hline $\begin{array}{l}\text { Mokrzyska- } \\
\text { Bucze }\end{array}$ & 247 & 1041 \\
\hline Brzesko & 151 & 344 \\
\hline Bielcza & 329 & 910 \\
\hline
\end{tabular}

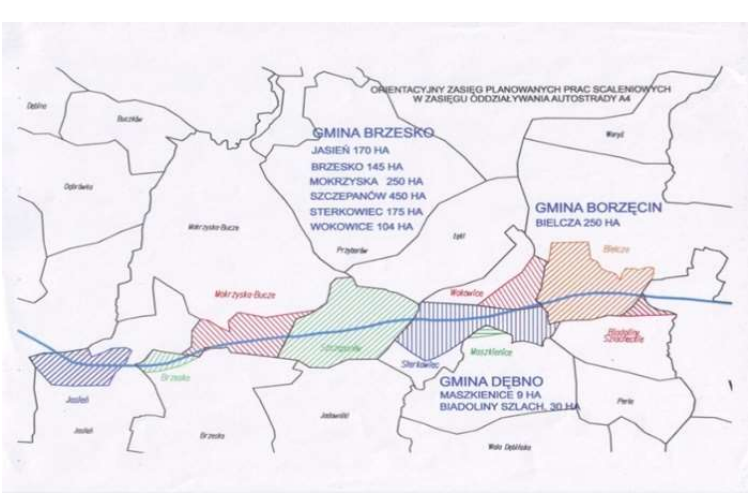

Fig. 4. Scope of planned consolidation works in the Brzesko poviat. Source: www.geodezja.powiatbrzeski.pl
The construction of a dual carriageway highway in the poviat was implemented in two sections: Szarów (without a node) - Brzesko (with a node) length $23.1 \mathrm{~km}$ and Brzesko (without a node) - Wierzchosławice (with a node) length $20.8 \mathrm{~km}$. The construction of both sections was completed in the second half of 2013. The mergers were divided into 6 internal proceedings, for which the most important data are presented in Table 1 and Fig. 4.

\subsection{Mergers in the area of the village of Szczepanów}

The proceedings were selected from among others in the poviat due to the advanced stage of the proceedings. The presented village, in which the consolidation process is carried out, is characterized by a flawed spatial structure of the land. The motorway contributed to an even greater disorganization of space. The area of the integration area amounted to 323,047 ha based on assumptions for the project elaborated in July 2010 by the Krakow Office of Geodesy and Agricultural Areas in Krakow. The impact of the motorway on arable and forest land was analyzed at the stage of "Application for a decision on the establishment of the A-4 motorway location" and is presented in the study "Assessment of the A-4 motorway impact on agricultural and forest land. The study shows that the negative impact of the motorway can be largely minimized primarily by the integration and exchange of land. In the preparation of the assumptions for the integration project, materials such as:

land registry database in graphic form;

- copies of cadastral maps;

- collective synchronization for the Szczepanów district;

- base map scans;

- a copy of the local zoning plan;

- extracts from land and mortgage registers

The contractor of the consolidation works, based on the above studies, concretized and determined the area of the study. The scope of the study has decreased in relation to the one that was initially presented in the "Impact assessment ..." where the need to carry out consolidation works on the area of 450 ha (the entire area of the area) was indicated. It was recognized that the improvement of the area structure in the area of the State Forest State Forestry Enterprise ( 6 plots occupying a total of about 120 ha) where the shapes and configurations of plots are correct seems to be pointless. The road network was considered sufficient to support the analyzed forest areas, and the planned motorway did not violate the communication system on the forest holding. The area was thus limited to about 323 ha (55\% of the area's area).

The analysis of the agrarian structure of the land, carried out on the basis of the inventory in the field, showed that the facts are significantly different from the data in the records. The largest differences are in arable land (5 and not $42 \%$ ) and grassland ( 8 instead of $24 \%$ ). There are 878 registered plots of land for private individuals, with a total area of about 253 ha, the average area of a private plot is 0.29 ha. There are 252 plots of land in the highway lane. The smallest plot has an area of $5 \mathrm{sm}$, while the largest is 5,74 ha. In one register unit there 
is usually one plot. There is a small number of different people's land in the area.

By virtue of a decision of November 30, 2011, district head of the Brzesko poviat initiated the merger proceedings in the area of the village. To carry out technical works and perform soil classification of grounds. The next stages of merging were started only in 2014 , ie 3 years after the initiation of the proceedings. The reason for such a long break was the lack of funds. Current information and relevant notices and other mercenary letters are posted on the Brzesko District Surveyor's website.

\subsection{Objectives of infrastructural consolidation}

The basic objectives to be achieved as a result of mergers in Szczepanów should be included in the justification for commencing consolidation proceedings. Belong to them: - improving the area structure of farms, reducing the number of plots in individual farms, reducing the number of plots with inconvenient shapes for mechanical cultivation;

- separation of land equivalent to farmers at a small distance from the farm's headquarters;

- demarcation and arrangement of a functional network of access roads to agricultural and forest land, adapted to currently used agricultural machinery;

- $\quad$ providing every post-office access to a public road;

- construction of new roads for agricultural transport, modernization and improvement of existing road parameters and their proper connection with the network of local and collective roads designed in the motorway belt;

- $\quad$ stabilization with permanent border marks of plots in the new post-calculation state;

- adjusting the boundaries of plots to the water melioration system and the relief system;

- current maintenance works of drainage ditches;

- $\quad$ separating the necessary land for technical and social infrastructure in the context of consolidation proceedings - without expropriation procedures;

- creating spatial conditions for the process of increasing the forest cover of the country;

- abolition of objectless and burdensome easements, abolition of joint ownership at the request of interested co-owners;

- creating conditions for synchronizing, in a systematic manner, cadastral documentation with land and mortgage registers

Detailed goals are included in the assumptions for the integration project carried out by KBGiTR and include:

- Improvement of the technical infrastructure of the agricultural production space: Nearly 25 ha, or approximately $8 \%$ of the area, will be deprived of access to a public road as a result of the construction of the motorway. Many of them are too narrow and unpaved, and will be devastated by traffic related to investment. In addition, the contractor examined that the technical condition of half of the drainage ditches can be described as bad or very bad.
- Improvement of the spatial structure of land: For this purpose, the most important is to reduce the number of plots on the farm as well as the whole area and to improve the layout of farms by moving plots closer to the habitat. It is also important to transfer the land of the residents closer to their town. The contractor also notes that the improvement of runners is the least predictable, but the most appreciated by the owners aspect of consolidation;

- Shaping the landscape and natural environment. It should be noted that the analyzed area is entirely within the area of the Protected Landscape Area of Bratislava, so interfering with the natural landscape should be kept to a minimum. The soil of the weakest classes should be allocated under tree stands. It is also proposed afforestation of areas adjacent to already forested plots.

\subsection{The course of the consolidation procedure}

To organize activities related to the consolidation process, three basic elements can be distinguished: initiation of proceedings, estimation of land value and a merge project. In the analyzed case, the initiation of consolidation proceedings, initiated by district head, took place in December 2011. In response to the requests of the land consolidation participants, raised at meetings, a list of registration plots entering the land consolidation area was published. In 2014, consolidation works are planned. In February 2015, the council of merge participants was selected at the meeting of merge participants. In the period January - March 2015. the act of gathering wishes from participants of merging was carried out, as to the future location of plots.

Simultaneously with the merger proceedings, proceedings related to the control of land classification were instituted, as the authority considered it advisable to ex officio classify on the land located in the merging area. The inspection was carried out in accordance with the provisions of the Regulation of 12 September 2012 on the soil classification of soil (Journal of Laws of 2010, No. 193, item 1287), where there are provisions regulating the course of proceedings in matters related to the subject matter soil classification of soil. Such control may be needed in order to update the registration inventory at further stages of consolidation.

Land estimate principles were adopted at the second meeting in June 2015. The developed land estimate map, after consultation with the advisory council, was used to estimate the value of the land. The results were announced at the meeting and then available for public inspection. When establishing the rules of respect, the land was managed:

- Agricultural usefulness according to the current condition of use, culture of cultivation, after the field interview;

- Destination in the Local Development Plan of the "Szczepanów" housing estate;

- Study of conditions and directions of spatial development of the Brzesko commune 
- Issued decisions on land development and development conditions.

It was considered that the value of the land should be determined according to the point scale of the so-called estimated units. The basic value is 1 ha. In the fourth quarter of 2015, activities related to the measurement of previously established boundaries of built-up plots (invariants) were completed. The boundaries of plots were determined in the presence of landowners or persons authorized by them. The results of findings were shown in field sketches and in the boundary reports. Limit points were measured using the GPS-RTK method with the GPS-Trimble R-8 receiver based on the ASG-EUPOS reference stations, as well as the LEICA TCR 407 Power total station. The GPS-RTK control measurement was made on the III class warp points. Deviations during control measurements did not exceed permissible deviations. Measurements were made of the measurements, coordinate lists and sketches of field sketches for the external border of the merging area and for built-up areas [3].

Finally, a new layout of plots was started using the wish list of the merge participants, shown in the merge participants' cards. The activities of bringing the project to the ground and then presenting the project were also initiated. The above activities were completed in the first quarter of 2016. Documents regarding the disclosure of changes in the Cadastre were also made regarding plots whose area differs from the area visible in the Katastra after establishing the boundaries, which results in exceeding the design deviation $+/-3 \%$ in the register after merging. For these plots, lists of changes in registration data were made to reveal changes in the Cadastre.

In September 2016, the Staroste notified the parties that they would publicly present the proposed and indicated project of land consolidation in the Szczepanów district.

\section{Conclusions}

Infrastructure mergers are a remedial tool, reorganizing the structure of land disturbed by the construction of a linear investment which is a motorway. Many benefits that are achieved through it allows to state that they are not only necessary, but often necessary. The final effect of the consolidation procedure is the update of the land registry survey on the basis of data obtained from field measurement. A redefinition of the areas that should be included in the merger could be useful. The optimal solution seems to be to designate entire villages to operate, which is currently not possible due to the provisions in the Act on land consolidation and exchange on financing consolidations in areas for which negative impact of the planned or implemented investment was found. In addition to the establishment of boundaries and areas, it is also important to determine the legal status of the property. As a result of land consolidation, a new numerical map is created as well as relevant geodetic and legal documentation necessary to reveal a new state in the land and land registry. Merging allows you not only to repair the existing problems, but also allows you to avoid many possible later, not necessarily the consequences of the built highway. The improvement of road architecture and drainage is also important.

Merging as a long and complicated process is carried out in stages. Each stage is important and should harmonize and complement each other accordingly. The experience of the consolidation process in Szczepanów area shows that the proceeding, despite such a large interference in the spatial structure and the chance to improve the disturbed structure of the land, is not given much interest to the residents. This is despite publicly available information about planned meetings and the openness of the bodies that merge any comments and reservations.

In practice, it is difficult to satisfy all participants of merging, and a large number of problems arise from ignorance - often inadequate information and lack of commitment. Therefore, it is necessary to make aware and seek compromises and expressions of willingness to cooperate with the owners, because consolidation is first and foremost a common chance to improve the quality of land use.

\section{Acknowledgement}

Publication supported by the Polish Ministry of Science and Higher Education as a part of the program of activities disseminating science from the project „Organization of the First International Science Conference - Ecological and Environmental Engineering”, 26-29 June 2018, Kraków.

This work was carried out within the statutory studies of the AGH University of Science and Technology, Faculty of Mining Surveying and Environmental Engineering, Department of Geomatics No. 11.11.150.006.

\section{References}

1. Ustawa z dnia 26 marca 1982 r. o scalaniu i wymianie gruntów (Dz. U. z 2014 r., poz. 700, z pózn. zm.)

2. Ustawa $\mathrm{z}$ dnia 23 kwietnia 1964 r. - Kodeks postępowania administracyjnego (Dz.U. 2016 poz. 23, z późn. zm.)

3. Ustawa $z$ dnia 17 maja 1989 r. Prawo geodezyjne $i$ kartograficzne (Opracowano na podstawie: t.j. Dz. U. z 2016 r. poz. 1629,1948 , z 2017 r. poz. 60.)

4. Hanus, P., Jasinska, E., Preweda, E. Analysis of the accuracy of determining the coordinates property borders. The 9th International Conference Environmental Engineering. Vilnius, Lithuania (2014)

5. Hanus, P., Pęska-Siwik, A., Szewczyk, R. Computers and Electronics in Agriculture, 144, p. 9-15. (2018).

6. Janus J., Taszakowski J., Korta G. Infrastruktura i Ekologia Terenów Wiejskich, Nr I/2, p. 333-346 (2017)

7. Jasińska E., Preweda E. Effect the accuracy of benchmarks to establish of the determination of geodetic network. The 9th International Conference 
Environmental Engineering. Vilnius, Lithuania (2014).

8. Leń P. Computers and Electronics in Agriculture 144: 216-221. (2018)

9. Leń P., Noga K. Journal of Ecological Engineering, Volume 19, Issue 2, pp. 248-256. (2018)

10. Len P. Methodology of hierarization of the work of land consolidation and land exchange. The World Multidisciplinary Earth Sciences Symposium (2017)

11. Leń P., Oleniacz G., Skrzypczak I. \& Mika M. Methodology for assessing the size and liquidation of the outer patchwork of land. World Multidisciplinary Earth Sciences Symposium (2017).
12. Leń P., Mika M. Journal of Ecological Engineering. Volume 17, Issue 4, pp. 163-169 (2016)

13. Leń, P., Król, Z. Journal of Ecological Engineering. Volume 17, Issue 5, pp. 232-239 (2016)

14. Sobolewska-Mikulska K. Infrastruktura i Ekologia Terenów Wiejskich,, Nr 1/II/, p. 41-51. (2012)

15. Szafrańska B. Scalenia infrastrukturalne jako narzędzie naprawcze przestrzeni planistycznej przeciętej budowana autostradą. Wydawnictwo Politechniki Krakowskiej. Z.3, 1-B (2011)

16. Wójcik J. Sobolewska-Mikulska K. Acta Sci. Pol., Geodesia et Descriptio Terrarum 11 (4) 27-38 (2012) 